Gut, 1975, 16, 429-436

\title{
Endotoxin-induced liver necrosis and intravascular coagulation in rats enhanced by portacaval collateral circulation
}

\author{
H. LIEHR ${ }^{1}$, M. GRÜN, H. THIEL, D. BRUNSWIG, AND U. RASENACK \\ From the Department of Medicine, University of Würzburg
}

SUMMARY The effects of intravenously administered endotoxin on the hepatic and systemic circulation as well as on the coagulation system were evaluated in normal rats $(\mathrm{n}=26)$, in rats with experimental portal hypertension $(n=15)$, and in rats with portacaval anastomosis $(n=22)$. Endotoxin $(1.5 \mathrm{mg} / \mathrm{kg})$ in the normal rat leads to a prompt increase of transaminase activity and to a hyperdynamic circulation with a consequent increase in the total hepatic blood flow. In a later phase ( $6 \mathrm{~h}$ postoperatively) the hepatic artery dilated with a consequent hepatic arterial hyperperfusion. The coagulation system was affected with signs of consumption coagulopathy.

In the rats with portal hypertension and portacaval collaterals as well as in those with portacaval anastomosis, the endotoxin injection resulted in acute liver necrosis within 12 to 15 hours. The hepatic artery became overdilated with a cardiac output fraction of $25 \%$ (normal $5 \cdot 5 \%$ ). Blood extravasates and thrombi, rich in fibrin, were detected in the liver. It is suggested that this exaggeration of the endotoxin effect was due to an impaired clearance function of the reticuloendothelial system, probably as consequence of portacaval collateral circulation. It is concluded that endotoxins (1) damage the liver even in a normal organism; (2) are potent to induce acute liver necrosis, if the reticuloendothelial system is altered; (3) have to be taken into consideration as contribution to the pathogenesis of acute as well as chronic liver diseases.

Endotoxaemia is of increasing interest in the pathogenesis of acute hepatic failure and its complications. It is proposed that endotoxins coming from the intestine are insufficiently cleared from the portal venous system because of an impairment of the reticuloendothelial system. Endotoxins may then be responsible for both the intravascular coagulation and renal failure which are part of the picture of acute liver failure (Wilkinson, Gazzard, Arroyo, Moodie, and Williams, 1974). Gans, Mori, Lindsey, Kaster, Richter, Quinlan, Dineen, and Tan (1971) discussed these problems in connexion with their experiments concerning the anhepatic dog and suggested from the results that bacteria from the intestine or their products, no longer adequately eliminated by the liver reticuloendothelial system, are contributing significantly toward the pathogenesis of hepatic failure.

${ }^{1}$ Author for correspondence: Priv-Doz Dr H. Liehr, 8700 Würzburg Med Univ Klinik, Josef-Schneider-Strasse 2, W-Germany

Received for publication 24 March 1975.
Though endotoxaemia occurs in acute liver failure (Wilkinson et al, 1974) and in chronic liver diseases (Caridis, Reinhold, ,Woodruff, and Fine, 1972), its effect is widely hypothetical and it is unknown whether endotoxaemia is contributory to the development of liver cell necrosis. In this study, therefore, the effects of intravenously administered endotoxin on the liver, the systemic and hepatic circulation, and the coagulation system were investigated in four experiments: (a) in a sequential study from the first to the seventh hour, and (b) during the period 12-15 hours after endotoxin administration both in normal rats, (c) in rats with portacaval anastomosis, and (d) in rats with prehepatic portal hypertension together with a spontaneous portacaval collateral circulation.

In the latter situations the liver is totally or partially out of contact with the portal blood. In this connexion it is of interest that in rats with portacaval anastomosis antibacterial lipopolysaccharide antibodies occur in the systemic circulation, indicating that an active portacaval collateral circu- 
lation may result in endotoxaemia (Keraan, Meyers, Engelbrecht, Hickman, Saunders, and Terblanche, 1974).

\section{Materials and Methods}

The animals used were non-fasted rats of the FW 49 strain (Dr K. Thomae, Biberach/R, W-Germany) and were kept under constant environmental conditions, such as day-night rhythm, temperature of $26^{\circ} \mathrm{C}$, and constant air moisture. Water and food (Altromin pellets; Altromin, Lage/L, W-Germany) were allowed ad libitum. Portacaval anastomosis was performed under light ether anaesthesia as described by Lee and Fisher (1961). Portal hypertension was induced by gradual occlusion of the portal vein, using vascular constrictors (Ameroid rings, Threepoint Products, Montreal/Cnd) as described previously (Liehr, Grün, Hörder, Pöschmann, and Binder, 1971).

Endotoxin, $1.5 \mathrm{mg} / \mathrm{kg}$ bw, was injected into the penile vein in normal rats $(n=26)$, in rats 28 days after portacaval anastomosis $(n=22)$ as well as in rats with gradual occlusion of the portal vein (six days postoperatively) $(n=15)$. The endotoxin preparation came from $E$. coli (026:B6, Difco Lab/Mich).

\section{Haemodynamic Investigations}

Hepatic blood flow was measured under pentobarbitone (Nembutal) anaesthesia $(40 \mathrm{mg} / \mathrm{kg}$ bw intraperitoneally) using the cardiac output fractionation method with 131I-MAA (radioactive iodinated macroaggregated albumin) injected into the left ventricle of the heart via the left carotid artery clamped cranially. The actual flow values were calculated from the cardiac output, which was determined using the modification of the Vierordts principle (Wollheim and Lange, 1931).

After having measured blood volume by the 125RIHSA-dilution method (Thiel, Grün, and Liehr, 1973) and the partial circulation time from the left inguinal vein to the left ear using indocyanine green as indicator together with an ear densitometer (Waters Inst Inc, Rochester/Minn, model PR 52), ' $\mathrm{K}$ ' in the equation for cardiac output was calculated from a normal cardiac output of $23.8 \mathrm{ml}$ $\mathrm{min}^{-1} / 100 \mathrm{~g}^{-1}$ (Richardson, Cooper, and Pinakatt, 1968). This method is described in detail elsewhere (Liehr, Grün, Krauss, and Rost, 1972).

Portacaval shunt volume was measured by the injection of 131I-MAA into a mesenteric vein. The radioactivity of the lungs in a percentage of recovery gave the portacaval shunt volume as a percentage of the splanchnic flow.

\section{Laboratory Investigations}

The coagulation factors II, V, VII, and $\mathrm{X}$ were determined with one-stage methods using commercial test reagents (Behring Werke, Marburg/L, W-Germany). Fibrinogen was measured by the method of Ratnoff and Menzie (1951). Platelets were counted by the method of Feissly and Lüdin (1949).

The activity of the serum glutamic oxalate transaminase (SGOT) and serum glutamic pyruvate transaminase (SGPT), serum bilirubin, and blood sugar concentrations were measured by conventional laboratory tests.

\section{Phagocytic Activity}

The phagocytic activity was estimated by the carbon clearance $(10 \mathrm{mg} / 100 \mathrm{~g}$ bw intravenously) as described by Benacerraf, Biozzi, Cuendet, and Halpern (1955).

\section{Histological Investigations}

Specimens of the liver, lungs, and kidneys were prepared for light microscopy by formalin fixation and stained with haematoxylin and eosin and by the method of Ladewig (1938) which also gives a staining reaction with fibrin.

\section{Time of Observations}

All parameters were determined 12-15 hours after endotoxin injection and for the sequential study in a group of normal animals from the first up to the eighth hour. Normal rats and untreated rats with portacaval anastomosis or portal hypertension served as controls.

\section{Statistics}

The values given in the tables are expressed as the means and the standard deviation. Statistical analysis was done using student's $t$ test or the Wilcoxon test. Statistical significance is expressed by the $p$ value (Student's $t$ test) or the $2 a$ value (Wilcoxon test).

\section{Results}

NORMAL RATS

The behaviour of the animals was altered from the first hour after endotoxin injection. They lost activity, showed hyperventilation, and developed erythema of the ears, snouts, and paws. 


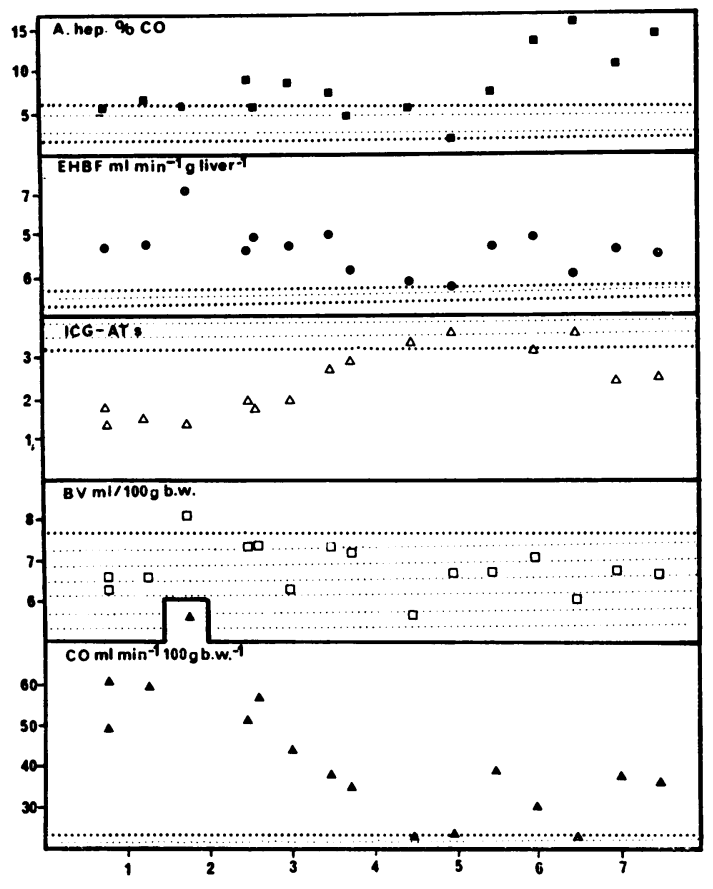

Fig. 1 Circulatory changes one to eight hours after a single injection of endotoxin in normal rats $C O=$ cardiac output $; E H B F=$ estimated hepatic blood flow; ICG-AT = indocyanine green appearance time; $B V=$ blood volume.

\section{Sequential study (first to eighth hour)}

As seen in fig 1 a single injection of endotoxin in normal rats leads to a decrease of the partial circulation time shortly after injection which tended to normalize from the fourth hour, whereas the blood volume was unaltered. The cardiac output was increased shortly after endotoxin administration and decreased to only slightly elevated values after the third hour.

The hepatic blood flow was found to be increased throughout the total period of observation. The flow fraction of the cardiac output of the hepatic artery increased from the sixth hour. The transaminase activities increased a short time after endotoxin administration up to values of about $300 \mathrm{mU} / \mathrm{ml}$ and were still raised to about threefold after eight hours (fig 2).

The coagulation system showed hypocoagulability with decreased fibrinogen concentration in the plasma, decreased activity of the factors V, VII, X, and a drop in platelets (table III).

The study of the liver by light microscopy revealed single cell necroses with pyknotic nuclei and a leucocytic reaction.
Later period after endotoxin injection

The changes observed 12-15 hours after endotoxin administration were principally the same as those at the end of the eighth hour (tables I-III).

\section{PORTACAVAL SHUNT RATS}

\section{Effect of portacaval anastomis in normal rats}

The clinical picture of the animals 28 days after portacaval anastomosis was abnormal. They developed a hump of the back and their activity was reduced.

The portacaval shunt volume was $99 \cdot 8 \pm 0.3 \%$ of the splanchnic flow; the portal pressure $6 \cdot 0 \pm 1 \cdot 4$ $\mathrm{mm} \mathrm{Hg}$ (controls $8.6 \pm 2.1 \mathrm{~mm} \mathrm{Hg} ; \mathrm{n}=27$ ). The cardiac output was increased to $135 \%$ of control. This was due both to an increase in blood volume and a decrease in the indocyanine green appearance time (ICG-AT). The arterial hepatic flow fraction increased to about $167 \%$ compared with normal controls. The actual hepatic blood flow in $\mathrm{ml} / \mathrm{min}$, calculated per gram liver, was reduced to $75 \%$ of normal; the hepatic blood flow in relation to body weight was decreased to about $30 \%$ of normal (table I).

The activities of the serum transaminases were elevated to about the double of normal values

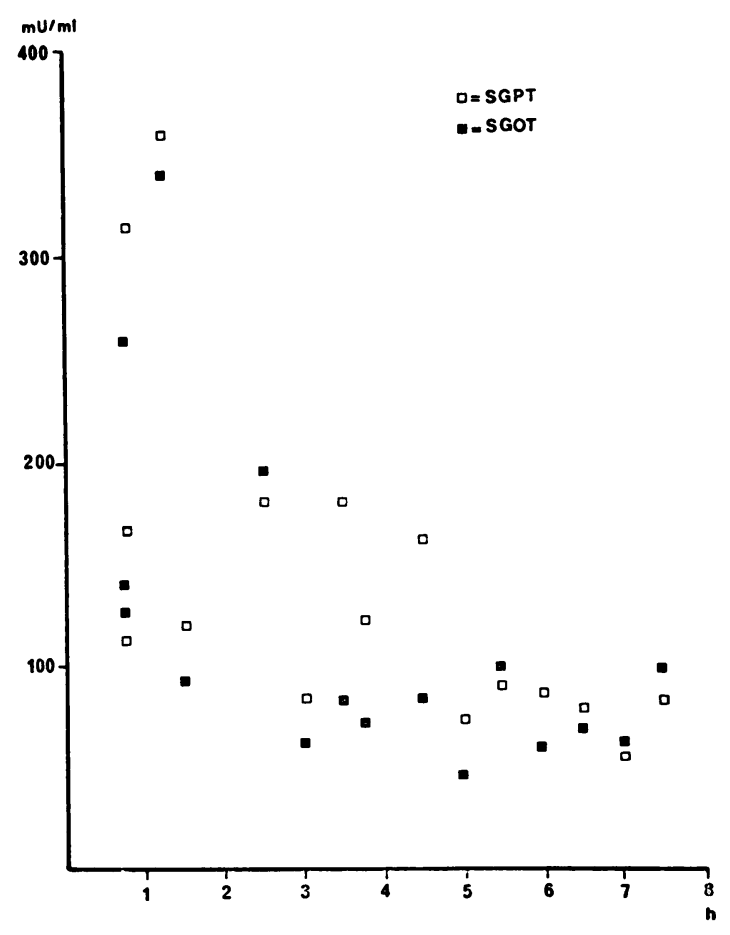

Fig. 2 Transaminase activities one to eight hours after a single injection of endotoxin it normal rats. 


\begin{tabular}{|c|c|c|c|c|c|c|c|c|}
\hline Experimental Conditions & $\begin{array}{l}\text { No. of } \\
\text { Rats }\end{array}$ & $\begin{array}{l}\text { Body Weight } \\
(g)\end{array}$ & $\begin{array}{l}\text { Blood Volume } \\
\text { (ml/100 g body } \\
\text { weight) }\end{array}$ & $\begin{array}{l}\text { Indocyanine } \\
\text { Green } \\
\text { Appearance } \\
\text { Time } \\
\text { (sec) }\end{array}$ & $\begin{array}{l}\text { Cardiac Output } \\
\left(\mathrm{ml} \mathrm{min}^{-1}\right. \\
\left.100 \mathrm{~g}^{-1}\right)\end{array}$ & $\begin{array}{l}\text { Hepatic Artery } \\
\text { ( } \% \text { of cardiac } \\
\text { output })\end{array}$ & $\begin{array}{l}\text { Hepatic B } \\
\left(\mathrm{ml} \mathrm{min}^{-1}\right. \\
\left.100^{-1} \mathrm{~g}\right)\end{array}$ & $\begin{array}{l}\text { Flow } \\
\qquad \text { g liver }^{-1}\end{array}$ \\
\hline $\begin{array}{l}\text { Untreated } \\
\text { controls }\end{array}$ & 31 & $\begin{array}{r}220 \\
+\quad 25\end{array}$ & $\begin{array}{r}6 \cdot 3 \\
\pm 1 \cdot 4\end{array}$ & $\begin{array}{r}3.6 \\
\pm 0.4 \\
\end{array}$ & $23 \cdot 8^{1}$ & $\begin{array}{r}5 \cdot 5 \\
\pm 2 \cdot 4\end{array}$ & $\begin{array}{r}10 \cdot 1 \\
\pm \quad 1 \cdot 4\end{array}$ & $\begin{array}{l}2 \cdot 0 \\
\pm 0 \cdot 3 \\
(1 \cdot 4-2 \cdot 7)\end{array}$ \\
\hline $\begin{array}{l}\text { With endotoxin } \\
12-15 \text { hr after injection }\end{array}$ & 9 & $\begin{array}{r}190 \\
\pm \quad 6\end{array}$ & $\begin{array}{r}6.9 \\
\pm 0.4\end{array}$ & $\begin{array}{r}2 \cdot 7 \\
\pm 0 \cdot 8\end{array}$ & $\begin{array}{r}36 \cdot 1 \\
\pm 9 \cdot 0\end{array}$ & $\begin{array}{r}11 \cdot 3^{5} \\
\pm 5 \cdot 4\end{array}$ & $\begin{array}{r}18 \cdot 3 \cdot \\
\pm 5 \cdot 3\end{array}$ & $\begin{array}{r}4 \cdot 1^{4} \\
\pm 1 \cdot 2\end{array}$ \\
\hline $\begin{array}{l}\text { Portacaval anastomosis rats } \\
28 \text { days after operation } \\
\text { With endotoxin } \\
12-15 \text { hr after injection }\end{array}$ & $\begin{array}{l}9 \\
7\end{array}$ & $\begin{array}{r}200 \\
\pm \quad 22 \\
229 \\
\pm \quad 21\end{array}$ & $\begin{array}{r}7 \cdot 1^{2} \\
\pm 0.9 \\
7.0 \\
\pm 0.8\end{array}$ & $\begin{array}{r}3.0^{3} \\
\pm 0.2 \\
3.6 \\
\pm 0.6\end{array}$ & $\begin{array}{r}32 \cdot 2 \\
\pm \quad 3.5 \\
26.8 \\
\pm \quad 5 \cdot 1\end{array}$ & $\begin{array}{r}8 \cdot 6 \\
\pm 2.9 \\
25 \cdot 0^{4} \\
\pm 11 \cdot 5\end{array}$ & $\begin{array}{r}2.9 \\
\pm \quad 1 \cdot 1 \\
6.6 \\
\pm \quad 3.1\end{array}$ & $\begin{aligned} & 1 \cdot 5^{5} \\
& \pm 0.6 \\
& 3 \cdot 0^{4} \\
& \pm 1 \cdot 3\end{aligned}$ \\
\hline $\begin{array}{l}\text { Experimental } \\
\text { portal hypertension } \\
\text { With endotoxin } \\
\text { 12-15 hr after injection }\end{array}$ & $\begin{array}{l}5 \\
4\end{array}$ & $\begin{array}{r}237 \\
\pm \quad 20 \\
292 \\
\pm 13\end{array}$ & $\begin{aligned} & 7 \cdot 5^{2} \\
& \pm 0 \cdot 2 \\
& 7 \cdot 5 \\
& \pm 1 \cdot 1\end{aligned}$ & $\begin{aligned} & 2 \cdot 8^{3} \\
& \pm 0.8 \\
& 2 \cdot 8 \\
& \pm \\
& \pm 0.6\end{aligned}$ & $\begin{array}{r}38 \cdot 3 \\
\pm \quad 8 \cdot 1 \\
39 \cdot 7 \\
\pm 03 \cdot 3\end{array}$ & $\begin{array}{c}8 \cdot 3 \\
\pm 3 \cdot 0 \\
21 \cdot 3 \cdot \\
\pm 4 \cdot 1\end{array}$ & $\begin{array}{c}8 \cdot 0 \\
\pm 2 \cdot 4 \\
13 \cdot 20 \\
\pm 4.81\end{array}$ & $\begin{array}{l}2 \cdot 3(\mathrm{n} . \mathrm{s}) \\
\pm 1 \cdot 0 \\
4 \cdot 0^{4} \\
\pm 1 \cdot 2\end{array}$ \\
\hline
\end{tabular}

Table I Circulatory changes after a single injection of $1.5 \mathrm{mg} / \mathrm{kg}$ body weight endotoxin intravenously in rats under different experimental conditions

${ }^{1}$ Richardson et al (1962); ${ }^{2} \mathrm{P}=<0.05 ;{ }^{3} \mathrm{P}=<0.0005$ (against normal values); ${ }^{4} 2 a=<0.01$ (against control); ${ }^{5} 2 a=<0.05$.

\begin{tabular}{|c|c|c|c|c|c|}
\hline Experimental Conditions & $\begin{array}{l}\text { No. of } \\
\text { Rats }\end{array}$ & $\begin{array}{l}\text { Bilirubin } \\
(\mathrm{mg} / 100 \mathrm{ml})\end{array}$ & $\begin{array}{l}S G O T \\
(m U / m l)\end{array}$ & $\begin{array}{l}S G P T \\
(m U / m l)\end{array}$ & $\begin{array}{l}\text { Glucose } \\
(m g / 100) m l\end{array}$ \\
\hline Normal rats & 22 & $\begin{array}{r}0.3 \\
\pm 0.2\end{array}$ & $\begin{array}{c}37 \\
\pm \quad 7 \\
(21-54)^{1}\end{array}$ & $\begin{array}{l}34 \\
\pm \quad 5 \\
(28-38)^{1}\end{array}$ & $\begin{array}{r}204 \\
\pm 42\end{array}$ \\
\hline $\begin{array}{l}\text { Endotoxin } \\
12-15 \mathrm{hr} \text { after injection }\end{array}$ & 9 & $\begin{array}{r}0.3 \\
\pm 0.1\end{array}$ & $\begin{array}{c}123^{2} \\
\pm \quad 74 \\
(42-220)^{1}\end{array}$ & $\begin{array}{l}142 \\
\pm 120 \\
\quad(30-234)^{1}\end{array}$ & $\begin{array}{l}146 \\
\pm 23\end{array}$ \\
\hline $\begin{array}{l}\text { Portacaval anastomosis rats } \\
28 \text { days after operation } \\
\text { With endotoxin } 12-15 \mathrm{hr} \text { after } \\
\text { injection }\end{array}$ & $\begin{array}{l}15 \\
18\end{array}$ & $\begin{array}{l}<0.3 \\
1 \cdot 0 \\
\pm 1 \cdot 2 \\
(0 \cdot 2-46)^{1}\end{array}$ & $\begin{array}{l}\quad 96^{3} \\
\pm \quad 34 \\
1119^{2} \\
\pm \quad 1153 \\
(140-4320)^{1}\end{array}$ & $\begin{array}{l}89^{3} \\
\pm \quad 50 \\
1131^{2} \\
\pm 126 \\
(152-4040)^{1}\end{array}$ & $\begin{array}{l}- \\
\quad 62 \\
+47 \\
(0-132)^{1}\end{array}$ \\
\hline $\begin{array}{l}\text { Experimental portal hypertension } \\
\text { Six days after operation } \\
\text { With endotoxin } 12-15 \mathrm{hr} \text { after } \\
\text { injection }\end{array}$ & $\begin{array}{r}5 \\
12\end{array}$ & $\begin{array}{l}<0.3 \\
\quad 0.73 \\
\pm 0.75 \\
(0 \cdot 1-2 \cdot 7)^{1}\end{array}$ & $\begin{array}{ll} & 60^{3} \\
\pm \quad 10 \\
1147^{2} \\
\pm \quad 618 \\
(300-2160)^{1}\end{array}$ & $\begin{array}{l}23 \\
\pm \quad 6 \\
700^{2} \\
\pm 592 \\
(118-2080)^{1}\end{array}$ & $\begin{array}{l}\overline{-} \\
\overline{86} \\
\pm 38 \\
(24-136)^{1}\end{array}$ \\
\hline
\end{tabular}

Table II Laborator' findings after a single injection of $1.5 \mathrm{mg} / \mathrm{kg}$ body weight endotoxin intravenously in rats under different experimental conditions

${ }^{1}$ range, ${ }^{2} 2 a=<0.01$ against control, ${ }^{3} 2 a=<0.01$ against normal values.

\begin{tabular}{|c|c|c|c|c|c|c|c|}
\hline \multirow[t]{2}{*}{ Experimental Conditions } & \multirow{2}{*}{$\begin{array}{l}\text { No. of } \\
\text { Rats }\end{array}$} & \multirow{2}{*}{$\begin{array}{l}\text { Fibrinogen } \\
(\mathrm{mg} / 100 \mathrm{ml})\end{array}$} & \multicolumn{4}{|c|}{ Coagulation Factors (\%) } & \multirow{2}{*}{$\begin{array}{l}\text { Platelets } \\
\text { per } \mathrm{mm}^{3}\end{array}$} \\
\hline & & & $\boldsymbol{I I}$ & $V I I$ & $\boldsymbol{X}$ & $\boldsymbol{V}$ & \\
\hline $\begin{array}{l}\text { Portacaval anastomosis rats } \\
28 \text { days after operation } \\
\text { With endotoxin } \\
12-15 \text { hr after injection }\end{array}$ & $\begin{array}{r}5 \\
10\end{array}$ & $\begin{array}{r}222 \\
\pm 56 \\
135 \\
\pm 53\end{array}$ & $\begin{array}{r}117 \\
\pm \quad 56 \\
45 \\
\pm 18\end{array}$ & $\begin{array}{r}- \\
51 \\
\pm 15\end{array}$ & $\begin{array}{r}- \\
46 \\
\pm \quad 22\end{array}$ & $\begin{array}{r}147 \\
\pm \quad 58 \\
\quad 66 \\
\pm \quad 35\end{array}$ & $\begin{array}{r}354 \cdot 200 \\
\pm \quad 36 \cdot 400 \\
79 \cdot 530 \\
+67 \cdot 135\end{array}$ \\
\hline
\end{tabular}

Table III Changes within the coagulation system after a single injection of endotoxin $(1.5 \mathrm{mg} / \mathrm{kg}$ body weight $)$ intravenously in rats under different experimental conditions 
(table II) and the liver showed some single cell necroses by histological investigation.

The coagulation system showed normal fibrinogen plasma concentration and unaltered activities of the coagulation factors II and V. The number of platelets, however, was significantly reduced (table III).

Blood glucose was found to be decreased. The carbon clearance test showed a decrease of phagocytic activity, which in normal rats was $K=0.034 \pm$ $0.011(n=12)$ but was decreased to $K=0.018 \pm$ $0.04(n=5)$ in the portacaval anastomosis rats $(\mathrm{P}=<0.0005)$.

\section{Influence of an endotoxin injection}

Twelve to 15 hours after intravenously administered endotoxin the rats showed signs of coma, sometimes up to stage III-IV. The animals lost physiological reflexes and consciousness at about the tenth hour. Three of 16 animals died in deep coma at the sixth hour. The data obtained at necropsy are listed in tables I-III. The arterial hepatic blood supply was markedly increased. The fraction of the cardiac output was $300 \%$ compared with portacaval anastomosis rats not treated with endotoxin and nearly $500 \%$ with normal controls. The actual hepatic blood flow increased twofold in endotoxin-treated rats compared with portacaval anastomosis controls.

The transaminase activity was extremely high, blood sugar concentration was low or even zero, and some of the animals developed hyperbilirubinaemia.

The coagulation system was hypocoagulable. The fibrinogen concentration was diminished to the same degree as in normal rats treated with endotoxin. The decrease of the activities of coagulation factors VII and $\mathrm{X}$ was more pronounced. The platelets decreased to $11 \%$ of normal values (table III).

At necropsy we found macroscopic bleeding in almost all organs, especially in the liver, lungs, and stomach. Three animals showed cortical necrosis of

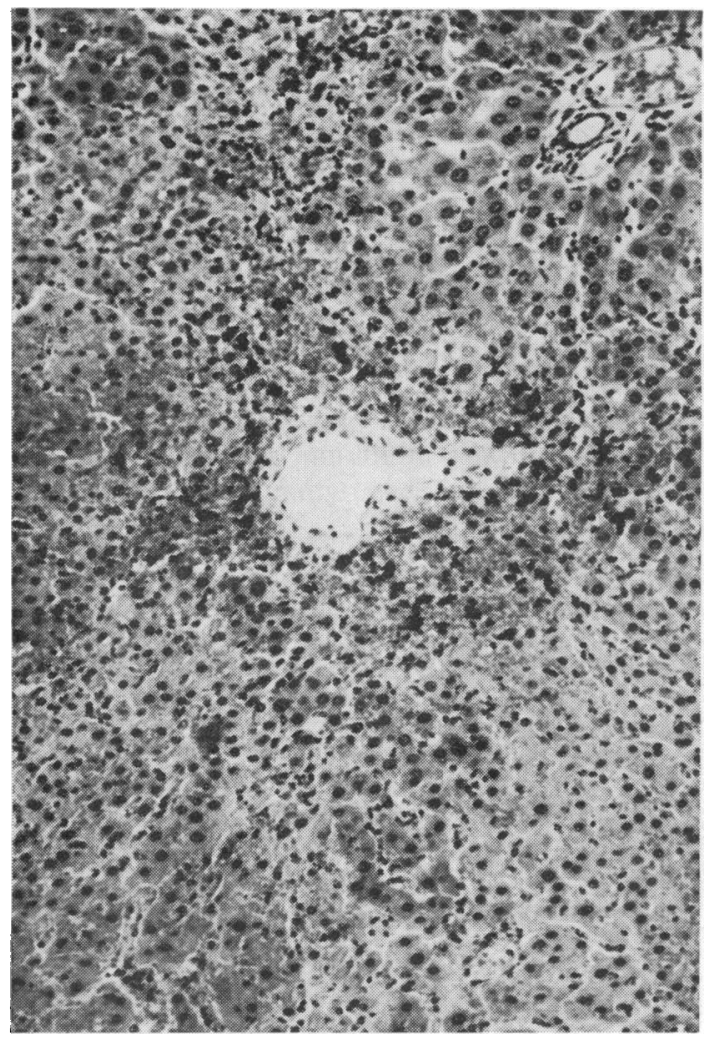

Fig. 3 Hepatic necrosis with blood extravasation in rats with portacaval anastomosis 12 hours after a single injection of endotoxin intravenously (haematoxylin-eosin $\times 70)$.

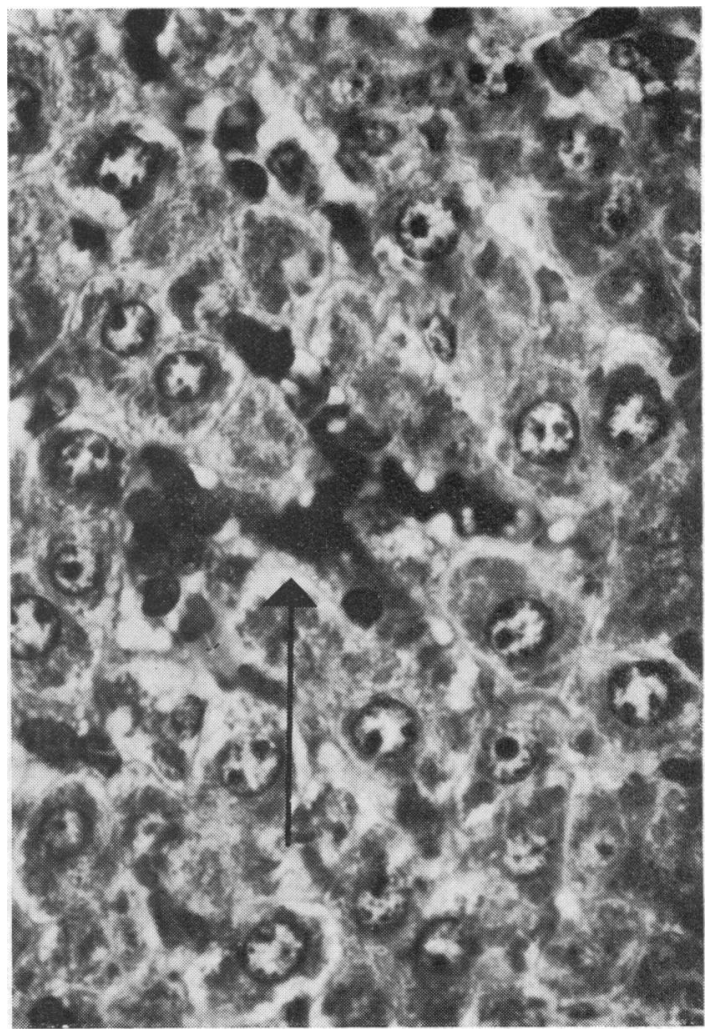

Fig. 4 Thrombus rich in fibrin $(\rightarrow)$ within the liver in rats with portacaval anastomosis 12 hours after a single injection of endotoxin intravenously (Ladewig stain; $\times 250$; green filter photograph). 
the kidney. By light microscopy the liver showed subtotal necrosis. Extravasates of blood were found in all the livers examined (fig 3). On special staining, thrombi, rich in fibrin, were seen in the sinusoids (fig 4).

EXPERIMENTAL PORTAL HYPERTENSION Effect on normal rats (six days postoperatively) Clinically the animals were unaltered. The portal pressure was increased to $14.0 \pm 1.2 \mathrm{~mm} \mathrm{Hg}$ (control $8.6 \pm 2.1 \mathrm{~mm} \mathrm{Hg} ; \mathrm{n}=22 ; \mathrm{P}=<0.01$ ). The portacaval shunt volume was $64 \pm 11 \%$ of the splanchnic flow. The portacaval collateral circulation was macroscopical as could be seen in dilatation of the oesophageal and haemorrhoidal veins as well as in collaterals to the left renal vein.

The cardiac output was high due to an increase of blood volume and a decrease of the partial circulation time. The fraction of the cardiac output to the hepatic artery was increased to $160 \%$ of normal, but the total hepatic blood flow in relation to liver weight was normal (table I).

\section{Effect of an endotoxin injection}

Three animals died in coma before sacrifice and seven 12 hours after endotoxin administration. Twelve to 15 hours after the administration of endotoxin we observed the same changes concerning clinical behaviour, haemodynamics and laboratory tests (tables I-II) as well as changes at necropsy as seen in the portacaval anastomosis group treated with endotoxin.

\section{Discussion}

\section{EXPERIMENTAL INVESTIGATIONS}

\section{Early effects of endotoxin}

The results of the sequential study in normal rats show that a single injection of endotoxin causes early and late effects. Concerning clinical behaviour, such as loss of activity, we cannot offer a real explanation, especially if it is due to a cerebral alteration. As early as from the first hour after endotoxin injection three further effects could be detected.

The increase in transaminase activities was thought to be signs of liver cell damage, confirmed by the histological investigation, where coagulation necroses of hepatocytes were detected. Filkins and Cornell (1974) likewise observed an early effect of endotoxin on the liver consisting of a rapid decrease of the gluconeogenetic rates when evaluated in vitro in isolated hepatocytes or in vivo in rats in both conditions pretreated with endotoxin 30-60 minutes before. In contrast they failed to observe this effect when endotoxin was added in vitro to normal hepatocytes of untreated rats. This indicates that the early effect of endotoxin on the hepatocytes seems not to be a direct action of the toxin. Yet the precise mechanism is unknown. The effect of endotoxin on glucose metabolism was also present in this study, as seen by the development of marked hypoglycaemia. Regardless of the mechanism, the data indicate an early effect of endotoxin on the liver.

A second early effect of endotoxin was the decrease in the circulation time. In connexion with the development of erythema of ears, snouts, and paws this was thought to be due to multiple arteriovenous shunts that had opened in the vascular periphery (Lambert, Ming, and Palmerio, 1969). As blood volume remained unchanged, $\mathrm{CO}$ increased as a result of changes in circulation time with an increase in total hepatic blood flow as a consequence. This situation disappeared and tended to normalize after the fourth hour.

A third early effect of endotoxin was observed on the coagulation system, which showed features of consumption coagulopathy. This interpretation of the data listed in table III seems clear, for the time of observation was too short to induce hypocoagulability due to a synthetic disorder. The changes are thought to be either a primary effect of endotoxin activating the Hagemann factor (Rodriguez-Erdmann, 1964) or to be a secondary effect of endotoxin, which damages the vascular endothelium (Lambert et al, 1969; McGrath and Stewart, 1969). Tissue thromboplastin or vasculokinase released from the vessel wall will then initiate the clotting system by the 'extrinsic' pathway of coagulation. This mechanism is favoured by the investigations of Müller-Berghaus and Lasch (1970) and MüllerBerghaus and Schneberger (1971). The authors demonstrated that inhibition of Hagemann factor did not prevent the Shwartzman reaction elicited by endotoxin.

\section{Later effect of endotoxin}

From the end of the fifth hour after endotoxin administration the arterial hepatic flow fraction of the cardiac output increased, demonstrating the vasodilatory effect of endotoxin (Lambert et al, 1969). Consequently, the total hepatic blood flow increased again as seen in the early phase of observation, but now only from the arterial side of perfusion (fig 1).

Altogether the sequential study suggests that endotoxin in normal rats is of influence and that the liver is affected twice by metabolic and haemodynamic alterations. The second experiment demonstrates that these changes were not transitory for a short period but persisted for 12 to 15 hours after endotoxin injection when the liver was still affected by arterial overperfusion. 
Endotoxin and portacaval collaterals

These effects of endotoxin were exaggerated in the third experiment under the conditions of portacaval anastomosis. A single injection of endotoxin was fatal for the animals and resulted in liver necrosis with clinical and laboratory signs of acute liver failure. The liver necrosis may be the result of both intrasinusoidal coagulation (fig 4), as part of the process of disseminated intravascular coagulation, and especially overdilatation of the hepatic artery with arterial hyperperfusion resulting in perfusion of each gram of liver, which was double that of normal. This may be the reason for the extravasation of blood into the liver parenchyma (fig 3).

From the experimental conditions it is conceivable that the portacaval anastomosis is the condition for this exaggerated effect of endotoxin. Under normal conditions endotoxin is sequestered by the macrophages of the reticuloendothelial system, especially in the liver and spleen sinusoids, and may be detoxified by their lysosomal apparatus (Filkins, 1972). From investigations by Benacerraf et al (1955) it is known that the phagocytic activity of the reticuloendothelial system is impaired by a reduction in hepatic blood flow. This situation is present in the portacaval anastomosis rats in which the total hepatic blood flow is about $30 \%$ of normal (table 1). In consequence, the phagocytic activity was found to be markedly decreased. Furthermore, the reticuloendothelial system in the liver is totally out of contact with the portal blood, and endotoxins from the gut are spilled into the systemic circulation, a statement which is supported by the investigations of Keraan et al (1974). These authors gave evidence of endotoxaemia in the portacaval anastomosis rat by the detection of antibacterial lipopolysaccharide antibodies in the systemic circulation. Further support for chronic endotoxaemia is given by the hyperdynamic circulation in the portacaval anastomosis rats, which can be induced even in normal rats by a single intravenous injection of endotoxin (fig 1). With regard to the mechanism of the ShwartzmanSanarelli reaction this situation has to be viewed as a priming dose of endotoxin. A single injection of endotoxin in the portacaval anastomosis rat then acts as a challenging dose for the ShwartzmanSanarelli reaction. This is confirmed by both the coagulation disorders as well as the necropsy findings with the classical features of the ShwartzmanSanarelli reaction in the rat, including bilateral renal cortical necroses (Gronvall and Brunson, 1956).

In the fourth experiment in connexion with portal hypertension the total hepatic blood flow was only reduced to $80 \%$ of normal values, and the contact of the reticuloendothelial system in the liver with the portal blood flow was maintained to $36 \%$ of normal. Also under these experimental conditions the Shwartzman-Sanarelli reaction could be induced, demonstrating that even a less extreme haemodynamic situation is potent to prepare the animals for that reaction.

\section{CLINICAL RELEVANCE}

It is difficult to compare animal experiments with human diseases, especially with regard to the large dose of endotoxin given to the animals, but the rat is known to be highly resistant to endotoxin (Grunvall and Brunson, 1956). Related to the data of Filkins and Cornell (1974), on the other hand, the dose used in this study was equivalent approximately only to $\mathrm{LD}_{15}$.

The present study carries implications for chronic liver diseases, especially cirrhosis, since under these conditions spontaneous or surgically induced portacaval anastomoses are present.

Clinical evidence for endotoxaemia in those patients is given by the investigations of Caridis et al (1972) who detected endotoxaemia in chronic liver disease, and by Triger, Alp, and Wright (1972) who found antibodies against Gram-negative bacterial antigens in advanced chronic liver diseases. Further evidence is given by the hyperdynamic state of the circulation in patients with cirrhosis of the liver, which was found to be dependent on the amount of portacaval shunt volume (Liehr, Grün, and Thiel, 1975) and is indistinguishable from the systemic haemodynamic disorders presented in this study.

Chronic consumption coagulopathy likewise is known as part of the picture of portal hypertension due to liver cirrhosis (Roberts and Cederbaum, 1972) and may also be triggered by endotoxins coming into the systemic circulation via portacaval shunts.

In consequence, it seems reasonable to speculate that patients with chronic liver disease and portacaval anastomoses are prepared like the animals in our experiments and in danger of the ShwartzmanSanarelli reaction due to Gram-negative sepsis. This may be the explanation for the severe liver diseases complicated by Gram-negative bacteraemia as observed by Martin, Spittel, Morlock and Baggenstoss (1956) and Caridis et al (1972).

In the light of the investigations of Wilkinson et al (1974) our results support the importance also of endotoxaemia in acute liver failure, but in which the hepatic clearance of intestinal endotoxins by the reticuloendothelial system may be diminished due to phagocytosis of necrotic material released from the liver. Endotoxin will then act, as observed in this study, as an additional alteration of the liver. The precondition for such an interpretation is the impairment of the functional state of the reticulo- 
endothelial system in the liver in acute liver disease. Evidence for this is given by clinical data from Cooksley, Powell, and Halliday (1973) who observed a decrease in the phagocytic function in patients with acute viral hepatitis. Further evidence is given by experimental investigations which have demonstrated a lethal effect of galactosamine-induced toxic liver damage under the conditions of a blocked reticuloendothelial system in the liver (Grün, Liehr, Grün, Rasenack, and Brunswig, 1974), and the investigations of Holper, Olcay, Kitahama, Miller, Brettschneider, Drapanas, Trejo, and Di Luzio (1974), who evaluated the influence on survival after hepatic ischaemia in baboons. They found a $100 \%$ death rate only in those animals in which a marked depression of phagocytic activity was present.

Though many problems concerning the connexion of endotoxaemia with liver diseases are as yet hypothetical, the importance of endotoxins is evident from both experimental and clinical investigations and must be taken into consideration.

The authors are grateful for the technical assistance of Ms G. Rumpel and U. Leonhard and Mrs Frf v Hutten.

\section{References}

Benacerraf, B., Biozzi, G., Cuendet, A., and Halpern, B. N. (1955). Influence of portal blood flow and of partial hepatectomy on the granulopectic activity of the reticuloendothelial system. J.Physiol.(Lond.), 128, 1-8.

Caridis, D. T., Reinhold, R. B., Woodruff, P. W. H., and Fine, J. (1972). Endotoxaemia in man. Lancet, 1, 1381-1386.

Cooksley, W. G. E., Powell, L. W., and Halliday, J. W. (1973). Reticuloendothelial phagocytic function in human liver disease and its relationship to haemolysis. Brit. J. Haemat., 25, 147-164.

Feissly, R., and Lüdin, H. (1949). Microscopie par contrastes de phases: applications àl'hématologie. Rev. haemat. 4, 481-501.

Filkins, J. P. (1972). Hepatic detoxification of endotoxin after adrenalectomy. Proc. Soc. exp. Biol. (N.Y.), 140, 212-215.

Filkins, J. P., and Cornell, R. P. (1974). Depression of hepatic gluconeogenesis and the hypoglycemia of endotoxin shock. Amer. J. Physiol., 227, 778-781.

Gans, H., Mori, K., Lindsey, E., Kaster, B., Richter, D., Quinlan, R., Dineen, P. A., and Tan, B. H. (1971). Septicemia as a manifestation of acute liver failure. Surg. Gynec. Obstet., 132. 783-790.

Gronvall, J. A., and Brunson, J. G. (1956). The generalized Shwartzman phenomenon in rats. Arch. Path., 62, 324-334.

Grün, M., Liehr, H., Grün, W., Rasenack, U., and Brunswig, D.
(1974). Influence of liver-RES on toxic liver damage due to galactosamine. Acta hepato-gastrent., 21, 5-15.

Holper, K., Olcay, J., Kitahama, A., Miller, R., Brettschneider, L., Drapanas, T., Trejo, R. A., and DiLuzio, N. R. (1974). Effect of ischema on hepatic parenchymal and reticuloendothelial function in the baboon. Surgery, 76, 423-432.

Keraan, M., Meyers, O. L., Engelbrecht, G. H. C., Hickmann, R. Sanders, S. J., and Terblanche, J. (1974). Increased serum immunoglobulin levels following porta caval shunt in the normal rat. Gut, $15,468-472$.

Ladewig, T. (1938). Ủber eine einfache Bindegewebsfärbung. $J$. microscop. Technol., 55, 215.

Lambert, P. B., Si Chun Ming, Ch. B., and Palmerio, C. (1969). Vasomotor factors in the Shwartzman phenomenon. Amer. J. Path., 57, 559-580.

Lee, S. H., and Fisher, B. (1961). Portacaval shunt in the rat. Surgery, 50,668-672.

Liehr, H., Grün, M. Hörder, M. H., Binder, H., and Pöschmann, A., (1971). Portale Hypertension der Ratte durch protrahierten Gefä $\beta \beta$ verschlu $\beta \beta$. Z. ges, exp. Med., 155, 267-272.

Liehr, H., Grün, M., Thiel, H., Krauss, H., and Rost, R. (1972). Hepatic blood flow in rats with galactosamine hepatitis. Actahepato-gastroent., 19, 259-263.

Liehr, H., Grün, M., and Thiel, H. (1975). Systemische Zirkulation bei portaler Hypertension.' Z. Gastroent., in press.

Martin, W. J., Spittel, J. A., Morlock, C. G., and Baggenstoss, A. H. (1956). Severe liver disease complicated by bacteremia due to gramnegative bacilli. Arch. intern. Med., 98, 8-15.

McGrath, J. M., Stewart, G. J. (1969). The effect of endotoxin on vascular endothelium. J. exp.Med., 129, 833-848.

Müller-Berghaus, G., and Lasch, H. G. (1970). Consumption of Hageman factor activity in the generalized Shwartzman reaction induced by liquoid: its prevention by inhibition of Hageman factor activation. Thrombos. Diathes. haemorrh. (Stuttg.), 23, 386-404.

Müller-Berghaus, G., and Schneberger, R. (1971). Hagemann factor activation in the generalized Shwartzman reaction induced by endotoxin. Brit.J. Haemat., 21, 513-527.

Richardson, A. W., Cooper, T., and Pinakatt, T. (1962). Thermodilution method for measuring cardiac output of rats by using a transistor bridge. Science, 135, 317-318.

Roberts, H. R., and Cederbaum, A. I. (1972). The liver and blood coagulation: Physiology and pathology. Gastrenterology, 63, 297-320.

Ratnoff, O. D., and Menzie, C. (1951). A new method for the determination of fibrinogen in small samples of plasma. J. Lab. clin. Med., 37, 316-320.

Rodriguez-Erdmann, F. (1964). Studies on the pathogenesis of the generalized Shwartzman reaction III: Trigger mechanism for the activation of the prothrombin molecule. Thrombos. Diathes. haemorrh. (Stuttg.), 12, 471-481.

Thiel, H., Grün, M., and Liehr, H. (1973). Bestimmung des intravasalen Verteilungsraumes bei der Ratte. Arzneimittel-Forsch., 23,979-981.

Triger, D. R., Alp, M. H., and Wright, R. (1972). Bacterial and dietary antibodies in liver disease. Lancet, 1, 60-63.

Wilkinson, S. P., Arroyo, V., Gazzard, B. G., Moodie, H., and Williams, R. (1974). Relation of renal impairment and haemorrhagic diathesis to endotoxaemia in fulminant hepatic failure. Lancet, 1, 521-524.

Wollheim, E., and Lange, K. (1931). Die Kreislaufzeit und ihre Beziehung zu anderen Kreislaufgrößßen. Verh. dtsch. Ges. inn. Med., 43, 134-140. 